\title{
East-Central Europe's changing energy landscapes: a place for geography
}

\author{
Abstract: \\ Energy developments in the post-Communist states of Eastern and Central Europe \\ (ECE) have a major impact on global energy security and sustainability, thanks to this \\ region's key geographical position between the energy-exporting states of the Former \\ Soviet Union, on the one hand, and the energy-importing states of Western and \\ Southern Europe, on the other. At the same time, post-socialist reforms of energy \\ industries in this region provide unique insights into the complex relations of power, \\ economic transformation and spatial inequality that govern energy production and \\ consumption. This paper, therefore, aims to provide an initial look at some of the \\ theoretical and policy issues that underpin the emergent 'geographies' of energy \\ reform in ECE, as well as their embeddedness in relations of power stemming from \\ organisational, infrastructural and economic inequalities in the region. It employs an \\ analysis of local news reports, policy papers, and statistical data to examine the \\ intricate institutional networks and spatial formations that have governed the energy \\ transformation process. In broader terms, the paper aims to emphasise the important \\ role that human geography can play in making sense of the territorial differences and \\ frictions that have emerged during the post-socialist reform process, while \\ challenging the idea of a 'neat' neoliberal transition from a centrally-planned to a \\ market-based mode of energy regulation.
}




\section{Introduction}

'The Russians plan to invade Britain' declared the UK's Daily Mail on the $27^{\text {th }}$ of May 2007, claiming that once a new Russian-German Baltic Sea pipeline comes on line within a few years, the EU will move into a position where any interruption of Russian natural gas supplies 'would be devastating'. The newspaper points out that Europe is already heavily dependent on Russia for its natural gas, which makes it unlikely that 'both the UK and Norway could resist the political pressure to share out the available gas' during a continent-wide energy shortage (Murray, 2007). This kind of rhetoric resembles the panic that swept across global media outlets and stock markets during the winters of 2006 and 2007, when Russia decided to temporarily shut off energy pipelines to, respectively, Ukraine and Belarus, as a result of bilateral disputes. Following the crises, high-ranking public officials in Austria, Poland, the Czech Republic and Italy, among other countries, called upon the EU to urgently reduce its dependence on Russian gas imports and formulate a common energy policy (BBC News, 2006).

The fact that Europe isn't an integrated energy space - in institutional, political, economic and technical terms alike - has a special resonance in the post-socialist countries of Eastern and Central Europe (ECE), which play a key role in the transit of hydrocarbon resources from the energy-rich states of the former Soviet Union and Central Asia, on the one hand, to the energy-poor but consumption-intensive states of Western and Southern Europe, on the other. The importance of 'energy geographies' in the ECE realm is underpinned by the fact that its constituent countries have been reforming their energy industries away from the legacies of the planned economy inherited from Communism. This temporal process has led to pronounced spatial disparities, as different countries, regions and towns have implemented the theoretical prescriptions for energy reform in different ways, thanks to different local mixtures of economic regulation, institutional cultures and political interests (for a further discussion, see von Hirschhausen and Wälde, 2001). Yet human geographers have had very little to say about the spatial and political implications of energy transitions in the ECE context, even though economists and political scientists have been active 
in this region for a number of years (but see Bradshaw, 1998; Bradshaw and Kirkow, 1998; Hayter et al., 2003; O’Lear, 2004; Ürge-Vorsatz, 2006). Most of the work in the field remains largely technocratic and descriptive, lacking a broader theoretical outlook.

Therefore, this paper aims to examine the broad-scale spatial implications of the energy sector reform process currently underway in Eastern and Central Europe. It investigates some of the relationships through which these emergent 'geographies' of energy reform have shaped, and been shaped by, spatial inequalities within the region. I am primarily interested in the national-level patterns of energy sector difference and differentiation that have appeared as a result of the post-Communist transition: can we make any general claims about the spatial 'stratification' of ECE states with respect to the reworking of energy production, distribution and consumption patterns? By using inherently geographical concepts - centring on issues of spatial differentiation and territorially-networked power relations - I wish to emphasise the crucial role that human geography can play in challenging the idea of a 'neat' transition from a centrally-planned to a market-based mode of energy regulation. In a broader sense, the paper aims to start a discussion about the adequacy and necessity of the neoclassical model of energy transformation, which claimed that the liberalisation and unbundling of energy activities can provide the most effective path for overcoming the economically and environmentally inefficient practices of Communist central planning (see, for example, Gray, 1995). I would like to destabilize the theoretical foundations of this paradigm, by pointing to the complex and 'messy' territorial variations, frictions, and energy reform outcomes that have emerged during the postsocialist transformation process.

The relative neglect of the relationship between energy infrastructure networks and the production of space within human geography is all the more surprising given Graham and Marvin's (2001) claim that large scale technological networks have the power to 'warp' and splinter space, while simultaneously tearing apart and binding together urban and regional tissues. The fact that infrastructures embody the 'congealed social interests' (Bijker, 1993) of their users and producers, while perpetuating 'an uneven development logic' (Pryke, 1999) points to the possibility of 
interpreting their organisational and material underpinnings through the lens of actor network theory (ANT) and science and technology studies (STS). Here, it is worth mentioning Hughes' (1993) exploration of the uneven geographical spread of electricity networks in Western societies, which has allowed studies of large technical systems to enter debates about the relationships between energy and space. Arguing along a similar line of thought, Star (1999) has identified a number of generic properties possessed by infrastructural systems, including the notion of embeddedness, transparency and scope.

Thinking about the role of infrastructures in the production of space has implications for the way in which one might conceive of the role of energy networks in the articulation of political and economic power across territory. While the multiple ways in which such power relations are employed in the construction of space and place are a frequent theme in the geography literature (as evidenced, not the least, by a number of recent articles in this journal: see, for example Few, 2002; McNeill, 2001; Neumayer, 2008) comparatively little has been written on the socio-technical linkages that allow the agency of energy networks to transcend national and regional borders. A useful entry point into such analyses may be provided by Sharp et al. (2000), who conceptualise power 'as an amalgam of forces, practices, processes and relations, [original emphasis] all of which spin out along the precarious threads of society and space' (page 20). The resulting 'entangled geography of power' is characterised by a topological shift from surfaces to filaments (Hinchliffe, 2000), suggesting that the establishment of power relations in space requires the 'careful plaiting of weak ties' which embody the 'stringy, ropy, capillary character' of modern societies (Latour, 1998; but also see Massey, 1993; Allen, 2003).

With these ideas in mind, the paper commences with an outline of the legacies of Communist central planning in ECE, both in terms of the physical structure of the energy sector (resource use, power plants, transmission infrastructures, consumption patterns) and its regulatory forms and practices. The next section of the paper examines the role of historical legacies and institutional frictions in energy restructuring, based on a variety of sources: local news reports, policy papers, statistical data published by international energy organisations. The paper's 
conclusion highlights the intricate threadworks of power and space revealed by the reviewed evidence. At this point, it should be emphasised that the sheer immensity of the subject matter, coupled with the almost complete lack of pertinent theoretical work within human geography, places major restrictions on the depth and breadth of any analysis. This paper thus isn't, and cannot be, anything like a comprehensive empirical account of energy reforms in post-socialism. Rather, it should be read as an initial attempt to pinpoint the key theoretical and policy issues that cut across the energy transformation process in this spatial realm, with the aim of paving the path for more detailed work.

\section{Communist legacies in the ECE energy sector}

Any analysis of current and recent energy developments in ECE is impossible without a prior examination of the common past of the countries in the region, embedded in the policies and strategies of Communist central planning. As far as energy issues are concerned, most of the literature agrees that the five decades of Soviet rule imposed a relatively similar set of decision-making practices across all ECE states. This is because Communist energy strategies were guided by a common set of ideologies, which stipulated that the energy sector should be an integrated component of social and industrial policies. As a result of this situation, all energy-related activities were centrally planned by the state, with the aim of ensuring universal access to energy resources, and fuelling the growth of heavy industry. The Leninist creed

'Communism is Soviet power plus the electrification of the whole country' provides a good summary of the energy planners' ideological approach during this period (for a further discussion, see, for example, Dienes and Shabad, 1979; Lewis, 1979; Pallot and Shaw, 1982).

The problem with Eastern Europe, however, is that it is not particularly well-endowed with energy resources. Fossil fuel sources are few and far in between, although the region's numerous tertiary basins do contain sizeable reserves of mainly low-grade coal. The Hungarian and Wallachian plains also possess some gas and oil deposits, and hydropower is abundant on the Danube and its tributaries, the slow but powerful rivers of Northeastern Europe that fall within the Baltic drainage, as well as the fast- 
flowing Albanian streams emptying into the Adriatic. Yet despite this situation, much of the region's hydroelectric potential, especially in countries like Romania, Poland, and even Slovakia, has remained unused; only Albania, Lithuania Bosnia and Croatia have managed to push the share of hydropower electricity generation capacity above the $40 \%$ mark (see Figure 1). Other sources of indigenous energy have included fuelwood - forest cover exceeds $60 \%$ in some countries (EEA, 2007) - and nuclear power: during Communism, seven nuclear plants were built in ECE, mainly along large rivers. Still, the bulk of the region's electricity supply has come from coalburning plants, most of which used to be heavy polluters during Communism, due to relying on low-grade fuels and/or inadequate technology (EBRD, 2001; AEA, 2008).

However, Russia and the Former Soviet Republics in the Caucasus and Central Asia possess vast energy reserves, ranging from oil and gas to hydropower and even geothermal energy. Thus, Communist central planning led most of the countries in the region - and particularly those in the Comecon ${ }^{1}$ - to become heavily reliant on energy imports from the Soviet Union. This dependence was married with political power, and cemented through a peculiar spatial-technical fix. Energy transmission infrastructures were constructed in such a way so as to allow centripetal links between the Soviet Union and the Comecon states, rather than lateral connections between the latter. This is evidenced by the fact that, for example, there were no direct hightension electricity lines between the Baltic republics and Poland, even though their energy grids were well connected with neighbouring Russia and Belarus (see Figure 2). In addition, Ukraine's Transcarpathian region, despite lacking any significant electricity generation facilities in situ, nonetheless contained an extremely dense intersection of high-tension lines that helped connect the Soviet Union with Slovakia, Hungary and Romania. In the southern part of the region, the total electricity transmission between Bulgaria and Romania (one $750 \mathrm{kV}$, three $440 \mathrm{kV}$ and one 220 $\mathrm{kV}$ line) was almost the same as all the remaining linkages between Bulgaria and its other neighbouring countries (three $440 \mathrm{kV}$ and three $110 \mathrm{kV}$ lines). However, unlike the former Yugoslavia, Greece or Turkey, Romania was in the Comecon, and also provided an overland link to the Soviet Union (GENI, 2008).

\footnotetext{
${ }^{1}$ Comecon, or the 'Council for Mutual Economic Assistance', was an international organisation aimed at facilitating aid, trade and other economic relations among Communist countries.
} 
Such divisions were further reinforced by the spatial distribution of oil and gas pipelines. Once again, the ECE countries themselves hardly possessed any direct North-South links, with most networks running between East and West, from the former Soviet Union to the Comecon countries in Eastern Europe, and then onward to Western Europe. Aside from serving very specific economic and political purposes within the energy sector - mainly linked to the construction of an energy interdependence within the Communist space, and the implementation of Communist development policies - the geographic spread of pipeline networks also played a major symbolic role in the spatial reproduction and 'rolling out' of Soviet power across ECE. In the imagination of public officials, these infrastructures were the main socio-technical 'threads' that would bind the vast territory of the Soviet Union and its satellite states into a coherent whole (the names of the pipelines - 'Friendship', 'Brotherhood', and so on - also testify to this perception). They also created a situation wherein most of ECE's oil and gas supplies came directly from the former Soviet Union. In countries like the Czech Republic, Slovakia, and Poland, the share of imported non-solid hydrocarbons from Russia surpassed 90\% (AEA, 2008; Hudovičová, 2003; IEA, 2005).

Many of the unsustainable environmental legacies of Soviet-style socialism in ECE can be connected directly to this interdependence. For example, in order to diminish their overwhelming reliance on Russian energy, ECE countries often encouraged the use of indigenous coal reserves. This created severe environmental problems, as such coal tends to be low grade lignite, which is also highly polluting and creates a lot of waste from by-products. But in addition to providing the main source of energy for the generation of electricity, coal was also extensively used by final consumers: industry, services and households. This complicated consequent environmental mitigation policies, since 'it is much more difficult or impossible to deal with the emissions generated by burning coal in small industrial boilers, heating plants, and domestic fires' (Hughes, 1991: 82), compared to large-scale, single-point sources like power plants. 
The energy legacies of Communist central planning were also reflected in the development of large scale district heating (DH) networks. These structures used large, centrally-placed combined-heat-and-power (CHP) or heat-only-boiler (HOB) plants to burn coal, fuel oil or - less often - natural gas, in order to produce hot water. The water was then transported through pipeline networks to substations, from where it was distributed to residential and industial consumers. Even though DH requires high population densities in order to justify its high capital costs - which made it an urban form of energy - Communist countries often constructed such infrastructures in smaller towns and even villages. This was particularly true in the former Soviet republics, as evidenced by the fact that they currently possess the highest shares of homes connected to DH, exceeding more than 50 per cent of all households (Buzar, 2007). However, the DH sector was also riddled with numerous energy efficiency problems, mainly stemming from the lack of metering and regulation (Kazakevicius et al., 1998; Lampietti and Meyer, 2002).

The unsustainable energy practices of Communist governments were supported by deeper economic and legal frameworks, which were, above all, embodied in the management structures and budgets of energy companies. The main policy instruments in this respect were the organisational and decision-making arrangements of the utilities themselves: they were 'vertically and horizontally integrated', while enjoying a monopolistic position on the market. Thus, a single company would be responsible for the generation, transmission and distribution of any one given type of energy (electricity, gas, oil) throughout any given country. Moreover, utilities were kept under strict control of the state, while it was made certain that their investment policies were aligned with broader industrial development objectives (Stern and Davis, 1998: 430; Crnobrnja, 1991).

Energy regulatory policies in Communism also incorporated a specific tariff policy, replete with indirect price subsidies and distortions. Although it is difficult to provide a comprehensive summary of the complex array of such pricing practices within the limits of this paper, it should nonetheless be noted that, generally, the prices of energy services bore 'no obvious relationship to the economic costs of production' (Stern and Davis, 1998: 430), due to an indirect economic subsidy to consumers, financed by the 
state 'forgoing revenues as the owner of the assets' (ibid.). This means that Communist countries possessed a 'system of low energy prices in absolute terms (below international levels) and, in particular, low prices for households' (Gray, 1995: 1). Such indirect subsidies were sustained 'by relatively high prices charged to industry, the revenues of which were used to cross-subsidise household prices' (ibid.). Energy pricing policies stemmed from the founding ideologies of Communist economies, whereby a number of essential goods and services - especially housing, heating and health - were treated as 'basic necessities' which were meant to be accessible to all. As a result, the consumption of state services by individuals and households 'was heavily subsidised ... both housing rents and public transport fares were kept very low' (Duke and Grime, 1997: 885). Moreover, most countries did not meter the individual consumption of gas, $\mathrm{DH}$, and in some cases even electricity, since the right to energy was considered an universal entitlement, rather than a service to be paid for.

One of the results of these policy approaches was the lack of adequate standards and investment in energy efficiency, both on the supply side of the sector, as well as across households, industry and services. The energy intensities of Communist economies were thus often more than twice the OECD average. While such trends varied drastically across different regions and states (Ürge-Vorsatz et al., 2003), it is important to note that their underlying ideology was the same. In terms of energy operations policies, they implied that Communism increased the level of homogeneity in a territorial realm otherwise characterised by deep internal disparities in its inherited levels of social and economic development (since it incorporated parts of the former Austrian, German and Ottoman empires). And yet the relatively common trajectories followed by ECE states in their energy policies during Soviet-style socialism began to diverge once again after the fall of the Iron Curtain.

\section{Post-1989 economic reforms: new spaces of transformation}

In ECE, the demise of Communist rule in the early 1990s marked the beginning of a deep restructuring of the centrally planned economy. Governments pledged to implement a market-based economic system, accompanied by a parliamentary, multi- 
party democracy. However, the nature and pace of economic reforms became a subject of deep disagreement and controversy among political and economic theorists. On the one hand, proponents of neoclassical 'market fundamentalism' advocated quick liberalisation and privatisation accompanied by fiscal and macroeconomic stabilisation, while on the other, 'institutionalists' and 'gradualists' argued that the post-socialist transformation cannot be implemented without first carefully setting up an adequate regulatory and organisational framework (Aslund, 2002). Yet neoliberal approaches eventually prevailed across the region, as Poland's 'shock therapy' model - derived from this country's stabilisation and liberalisation programme initiated in 1990 - was soon followed by most countries in the region (Marangos, 2002).

The neoliberal model was also implemented in the energy sector, where the dominant prescription for economic and institutional restructuring suggested that governments 'unbundle' integrated energy companies, while removing cross subsidies, liberalizing the tariff structure and allowing free access to the energy market (Stern and Davis, 1998). Many of these suggestions were based on efficiency arguments, which stipulated that "post-socialist countries should increase prices for energy resources to reflect their real marginal cost and thereby provide consumers with a positive economic incentive to conserve energy' (Kramer, 1991:14). It was claimed that 'the target of reducing the overall energy intensity of GDP by 50 per cent for Bulgaria, Czechoslovakia and Poland, and by 30 per cent for Hungary within 10 years is a goal that can be achieved by a combination of pricing policies and industrial restructuring to improve or eliminate the most wasteful industrial activities' (Hughes, 1991: 96). International financial institutions operating in the region - the World Bank, IMF, European Bank for Reconstruction and Development (EBRD), and so on - provided the logistical backing for this approach, mainly because their policies had the power to drive energy-related government decisions through various forms of loan conditionality (for example, see the EBRD's energy policy, EBRD, 1999: 10). Their neoliberal orientation was further reinforced by the EU accession process, which expected countries to align their Acquis Communautaire with the EU Liberalisation Directive, which incorporates a very similar set of policy principles. 
A key question that has rarely been raised in this context is what kind of spatial patterns can emerge from the imposition of a relatively similar 'package' of policy principles on a very heterogeneous group of states - in economic and spatial terms alike - which also inherited a number of common legacies from their immediate past. To what extent would policy transformations in the domains of energy efficiency, market reform and infrastructure investment be embedded in local contingencies, versus broader forces of transformation? This question has rarely been treated in an integrated way, as the role of socio-economic and physical space - as a container of legacies, frictions, constraints, enablements, and an active agent of change - has rarely been seen through a single conceptual lens.

\section{Divergent trajectories of change in the restructuring of energy operations}

A broad-scale overview of energy sector reforms across the post-socialist space suggests that the last 17 years of post-Communist transition have produced very different outcomes in different countries, regions, and even cities. This is despite the fact that nearly all of these states have faced similar issues in the restructuring of energy industries, organisational policy practices, and state institutional configurations. In general, it can be said that political resistance - to various degrees and an in different forms - to utility unbundling, market liberalisation and privatisation has been ubiquitous across the region. Many countries have also experienced extensive state interference in energy companies, as governments have been unwilling to relinquish control of such key political and economic instruments of power. There has been slow progress towards implementing comprehensive policies for energy efficiency improvement, leading many countries to maintain the high energy intensities inherited from socialism. Finally, most states have invested an insufficient amount of capital in energy, and particularly electricity, infrastructures, both in terms of the construction of new generation and transmission capacity, as well as the maintenance and upkeep of existing facilities (see, inter alia, EBRD, 2001 for an in-depth discussion).

Yet these general trends hide a more intricate smaller scale picture. Von Hirschhausen and Wälde's (2001) comprehensive international-level analysis of the 'stylised' 
patterns of energy transformation across the post-socialist space reveals that former Soviet states possess a mixed regime of energy regulation, where elements of the free market co-exist with remnants of Communism. In such states, they argue, the boundaries between state, industry and party/clan affiliations are heavily blurred and intertwined. But the various institutional traps (Buzar, 2005) and 'hysteresis effects' (Yavlinsky and Braguinsky, 1994) inherited from the previous economic regulation have been less pronounced in ECE, as the pressure to implement market-based energy reforms has been significantly stronger in that region. However, even here major differences among countries are in evidence, mainly due to the various institutional settings for energy industries. In the electricity sector, the replacement of policydriven energy regulatory practices with market-orientated ones has taken different forms in different countries, as a result of local economic and political particularities (see Table 1). In principle, nearly all countries have 'unbundled' electricity monopolies into separate generation, transmission and distribution companies, while adopting the 'regulated third party access' (RTPA) model for liberalizing power exchanges. Under this set of rules, eligible consumers are allowed to purchase their electricity directly from the generators or intermediary companies, while all other customers must obtain their energy from transmission and distribution incumbents on the basis of published tariffs. The model is supposed to lead to competition at both the generation and distribution stage. To date, it has been implemented in most Central European and Baltic (CEB) states (see IERN, 2008; von Hirschhausen and Zachmann, 2005; Kaderják, 2005; Hudovičová, 2003; Kennedy, 1999)

The RTPA, however, is not the only form of market liberalisation, as the 'single buyer model', while being effectively outlawed by the EU liberalisation directive, still survives de facto in some countries of the region. This is a system whereby eligible customers can only access generators and/or the high voltage grid through a single buyer and seller. Competition, access to the market, as well as transmission fees and tariffs for non-eligible customers are overseen by an independent regulator, while the function of running the grid is entrusted to a 'technical' system operator, usually associated with the single buyer (Brendow, 2001). In addition to the peculiar 'hybrid' model employed by Hungary (Pešić and Ürge-Vorsatz, 2001; ECEE, 2002) such systems have been prevalent in many Balkan states, although some of them - most 
notably Bosnia, Serbia and Montenegro - are at the beginning of the unbundling process. The implementation of the RTPA in such countries, despite being a clearly declared political priority, has been hampered by the continued presence of implicit energy subsidies. These mainly take the form of non-cost based pricing mechanisms, tolerance of non-payment, or energy theft (AEA, 2008; IERN, 2008; ERRA, 2008; SECQ, 2004).

While the two regulations have produced different levels of 'market opening' - which can be defined as the share of consumers who can freely choose their electricity supplier - liberalisation across all of ECE has been further constrained by the different definitions of the term 'eligible' customers within the RTPA, as well as the imposition of import licences and other restrictions on trade. Estonia is a good illustration of this set of conditions - in 2007 , only $12 \%$ of its electricity market was for competition, drawing constant criticism from the European Commission (IERN, 2008; EC, 2006). Moreover, national energy trade in most countries continues to be dominated by a limited set of large generation companies, due to the small size of the market. This issue is particularly pronounced in the gas sector, where, despite being formally unbundled in most countries, production and even transport functions are still controlled by the large integrated utilities that grew out of the former state monopolies. In some cases (most notably Lithuania, Poland, Slovakia and Croatia) these companies have not been privatised to date (IERN, 2008; ERRA, 2008).

The energy privatisation process has acted as a key factor of spatial and institutional differentiation within the post-socialist realm. In this respect, there is a clear difference between the EU accession states in CEB, on the one hand, and the remaining post-socialist states further south (not to mention east), on the other. While the former have been relatively quick and efficient at relinquishing control of their state-run electricity companies to foreign investors, the privatisation dynamic in the latter has been proceeding at a much slower pace, and amidst institutional friction. However, there are some notable exceptions even within the CEB region: for example, most generation facilities in the Czech Republic are still owned by the former state electricity monopoly, whose sale was scrapped on several occasions due to the insufficient quality of privatisation bids (IEA, 2005). Latvia and Slovenia have 
likewise refused to sell their electric power generation plants - and in the case of Slovenia, even distribution companies - in the face of widespread public opposition (Filippini et al., 2004). Resistance to privatisation has been even higher in the case of the CEB gas sector, where state ownership dominates the industry even in countries like Poland, which have otherwise been at the forefront of the liberalisation process (IERN, 2008). Thus, unlike other parts of the economy, where private capital has been overwhelmingly present for a considerable time, the energy domain displays a real patchwork of public and private ownership across the post-socialist space, with the proportion of the former tending to increase as one moves south (AEA, 2008; Kreibig et al., 2001; ERRA, 2008).

Here, it is worth noting that the quicker move towards a market regulation has not helped CEB states overcome some of the structural legacies of the Communist era. There is no clear geographic pattern in the energy intensities of post-socialist economies, which are well above the EU average across the region (although Serbia stands out with its exceptionally high levels, see Table 1). A similar picture exists in the case of emissions, although they tend to be higher in per capita terms in the CEB region, while the Balkan states generally emit more $\mathrm{CO} 2$ compared to the size of their economies. Still, the pace of energy intensity reduction has been quicker in CEB, thanks to the more effective implementation of energy efficiency policies, accompanied by the faster introduction of new technologies (for example, Poland has reduced its energy intensity by 46\% in PPP terms between 1989 and 2002, see Ürge Vorsatz et al., 2006). But even in this region, much of the power generation infrastructure has yet to be replaced with more modern and less polluting facilities. Russia remains the dominant source of hydrocarbons for many of its constituent countries, forcing them to continue to rely on polluting, indigenous coal for much of their electricity supply, in the name of energy security. And yet these problems fade in comparison to the Balkan countries, which continue to maintain an energy-inefficient industrial structure. Their electricity generation facilities will require significant levels of refurbishment and upgrading in the near future if the current levels of energy production are to be maintained (AEA, 2008; ERRA, 2008; IERN, 2008; Jasiński and Pfaffenberger, 2000; SECQ, 2004). 
Thus, it is evident that the 'real life' reform paths in the energy sectors of ECE states have seldom been uniform and neat. This is despite the fact that all of them inherited a common set of legacies from the Communist regulation, having then adopted - at least nominally - a similar set of restructuring approaches. Factors such as the degree of state interference, energy market structure, level of liberalisation, entry of private capital, the presence of implicit subsidies, and energy efficiency have all varied from country to country, and even within the countries themselves. Still, and notwithstanding these general trends, there is a clear macro-level pattern that distinguishes the new EU-8 member countries in Central Europe and the Baltic (CEB) from the remaining ECE states in the Balkans. The regulation of the energy sector in CEB countries has now more or less converged with the remaining 15 'older' EU states, even though the liberalisation process has been slowed down by the relevant governments' reluctance to implement full legal unbundling and access to the market. However, in the Balkan countries further south - including the latest EU members Romania and Bulgaria - energy restructuring has further deviated from the 'ideal' neoliberal path. These countries possess a hybrid regulation of the energy sector, with a greater degree of state capture and institutional friction.

The emergence of different geographic patterns in the nature and extent of energy sector transformations attests to the presence of an inherent spatial variation in the underlying institutional and political contingencies of the energy reform process. In this context, it should be noted that such relationships are mainly visible at the national scale, since most energy policy decisions are indeed formulated and implemented at the level of nation states. At the same time, however, it is also true that the real-life trajectories of reform represent an incongruous amalgamation of networks operating along different routes. On the one hand, theoretical paradigms of post-socialist transformation and international institutions imposed 'from above' have ushered energy policies in a neoliberal direction, putting pressure on decision-makers whenever they have been perceived to be straying from the prescribed norm. Yet on the other, path-dependent socio-technical networks have shaped the realities of energy sector governance 'from below', giving them practical content and meaning (for a wider discussion of path-dependency in post-socialism, see inter alia, Sykora, 2008). It can thus be suggested that the neoliberal reform paradigm in this spatial context has 
been significantly constrained and modified by power relations emanating from the local and regional scales.

\section{Conclusion}

The evidence reviewed in this paper indicates that post-socialist energy sector reforms are exhibiting the ability to both produce places and be conditioned by them. The energy restructuring process is affected by locally-contingent historical, cultural and economic relations that are in a perpetual clash with the new set of heterogeneous ties imposed by the post-socialist energy restructuring process (Dunford and Smith, 2000). This has been demonstrated by the emergence of geographical differences in the reform of electricity operations, conditioned by the path-dependencies contained within different locales. Moreover, energy governance has taken place 'in a field of tension between governance based on market and institutions (and the rule of law) on the one hand, and state-centred, power-based geopolitics on the other' (Westphal, 2006: 58), which means that many crucial decisions in the energy sector have been affected by the friction between different layers of regulation and power relations.

Such developments may lead us to question the dominant theoretical paradigm of energy sector reform in post-socialism. Rather than the neat sequence of neoliberal economic policies foreseen by mainstream energy theories, post-socialist countries have experienced a much more complex and variegated path of energy restructuring, underpinned by issues of power, space, path-dependency and place-making. An improved understanding of the reasons why particular countries, regions and cities have shaped, and been shaped by, the trajectories of energy policy reform may provide the basis for undermining the myth of a 'single solution' to energy restructuring $(\mathrm{Xu}, 2006)$ that has provided the main theoretical template for policy reforms in Eastern Europe and other developing countries to date.

Unravelling the institutional aspects of energy transformation in this region is all the more important in light of Europe's potentially increasing reliance on Russian overland gas imports, which will inevitably use Eastern Europe as a transit space. The lack of a common EU energy policy to respond to the complex political, 
infrastructural and economic challenges associated with governing power relations and institutional reforms in a geographical realm that is increasingly spatially fragmented and heterogeneous could have an adverse impact on the EU member states' individual abilities to obtain a secure source of energy supply, while formulating a sustainable energy policy.

As a 'mixed', hybrid discipline that has the ability to 'transcend the science wars' (Whatmore, 2002), geography is in an optimal methodological and conceptual position to unravel the spatial contingencies of the energy restructuring process in ECE, as well as its territorial, political and economic implications. The importance of its potential role in this context becomes all the more evident in light of the fact that as I have attempted to show in this paper - spatial formations at different scales are deeply enmeshed, and indeed indicative of, national-level patterns of energy sector differentiation that have emerged in the region. With their established knowledge of the multiple spatial outcomes resulting from the interactions of infrastructure, society and economy at different scales (for example see Solomon et al. 2004), geographers are ideally positioned to take a leading role in this process, as the discipline already has the analytical tools to interrogate the role of spatially-embedded pathdependencies and development trajectories in the energy restructuring process. 


\section{References:}

AEA (Austrian Energy Agency) 2008 Energy in Central and Eastern Europe http://www.eva.ac.at/enercee Accessed on 9th May, 2008

Allen J 2003 Lost Geographies of Power Blackwell, Oxford

Åslund A 2002 Building Capitalism: The Transformation of the Former Soviet Bloc Cambridge University Press, Cambridge

BBC News 2006 Italy hit by Russian gas shortage http://news.bbc.co.uk/1/hi/business/4625092.stm Accessed on 1 August, 2008

Bijker W 1993 Do not despair: there is life after constructivism Science, Technology and Human Values 18 113-138

Bradshaw MJ 1998 Going global: the political economy of oil and gas development offshore of Sakhalin Cambridge Review of International Affairs 12 147-176

Bradshaw MJ and Kirkow P 1998 The energy crisis in the Russian Far East: origins and possible solutions Europe-Asia Studies 50 1043-1064

Brendow K 2001 Privatizing and Regulating the Electricity and Gas Industries in Central and Eastern Europe: Models, Status, Issues Macedonian Academy of Sciences and Arts, Skopje

Buzar S 2007 Energy Poverty in Eastern Europe: Hidden Geographies of Deprivation Ashgate, Aldershot

Crnobrnja M 1991 Yugoslavia's energy choices and the economic dimension in DeBardeleben J ed To Breathe Free: Eastern Europe's Environmental Crisis Woodrow Wilson Center Press, and Johns Hopkins University Press, Washington, D.C, Baltimore, London 169-189

Dienes L and Shabad T 1979 The Soviet Energy System V. H. Winston \& Sons, Halsted Press, New York

Duke V and Grime K 1997 Inequality in post-Communism Regional Studies 31 883-890

Dunford M and Smith A 2000 Catching up or falling behind? Economic performance and regional trajectories in the "new" Europe Economic Geography 76 169-195

EBRD (European Bank for Reconstruction and Development) 1999 Energy Operations Policy EBRD, London

EBRD (European Bank for Reconstruction and Development) 2001 Transition Report 2001: Energy in Transition EBRD, London

EC (European Commission) 2006 The Commission to act over EU energy markets http://europa.eu/rapid/pressReleasesAction.do? reference $=M E M O / 06 / 481 \&$ format $=H$ $T M L \&$ aged $=0 \&$ language $=E N \&$ guiLanguage $=e n$ Accessed on 6th May, 2008 
ECEE (Export Council for Energy Efficiency) 2002 The Market for Energy Efficiency in Hungary http://www.ecee.org/pubs/hungary.htm Accessed on 10th June, 2008

EEA (European Environment Agency) 2007 Europe's Environment - The Fourth Assessment EEA, Copenhagen

ERRA (Energy Regulators' Regional Association) 2008 Member profiles http://www.erranet.org Accessed on 19th June, 2008

Few R 2002 Researching actor power: analyzing mechanisms of interaction in negotiations over space Area 34 29-38

Filippini M, Hrovatin N and Zorič J 2004 Efficiency and regulation of the Slovenian electricity distribution companies Energy Policy 32 335-344

GENI (Global Energy Network Institute) 2008 National Energy Grid Map Index http://www.geni.org/globalenergy/library/national_energy_grid/index.shtml Accessed on 20th July, 2008

Graham S and Marvin S 2001 Splintering Urbanism: Networked Infrastructures,. Technological Mobilities, and the Urban Condition Routledge, London and New York

Gray D 1995 Reforming the Energy Sector in Transition Economies: Selected Experience and Lessons World Bank, Washington, D.C.

Hayter R, Barnes TJ and Bradshaw MJ 2003 Relocating resource peripheries to the core of economic geography's theorizing: rationale and agenda Area 35 15-23

Hinchliffe S 2000 Entangled humans: specifying powers and their spatialities in Sharp JP, Routledge P, Philo C and Paddison R eds Entanglements of Power: Geographies of Domination/Resistance Routledge, London and New York 219-237

Hudovičová N 2003 Slovak Electricity Market Model (http://www.erranet.org/index.php? name $=O E-$ eLibrary\&file $=$ download\&id $=1144 \&$ keret $=N \&$ showheader $=N$ ) Accessed on 19th June, 2008

Hughes G 1991 The energy sector and problems of energy policy in Eastern Europe Oxford Review of Economic Policy 7 77-98

Hughes TP 1993 Networks of Power: Electrification in Western Society, 1880-1930 Johns Hopkins University Press, Baltimore

IEA (International Energy Agency) 2005 Energy Policies of IEA Countries: The Czech Republic OECD/IEA, Paris

IERN (International Energy Regulation Network) 2008 Regulation by Country http://www.iern.net/regulation/wwl.htm Accessed on 19th June, 2008

Jasiński P and Pfaffenberger W 2000 Energy and Environment: Multiregulation in Europe Ashgate, Aldershot 
Kaderják P 2005 A Comparison of Electricity Market Models of CEE New Member States SESSA Working Paper no. 14, Budapest

Kazakevicius E, Schipper L and Meyers S 1998 The residential space heating problem in Lithuania Energy Policy 26 859-872

Kennedy D 1999 Competition in the Power Sectors of Transition Economies EBRD, London

Kreibig U, Opitz P and von Hirschhausen C 2001 The power sector in Central and Eastern Europe: more competition needed in the run-up to EU membership Economic Bulletin $3833-38$

Lampietti J and Meyer A 2002 When Heat is a Luxury: Helping the Urban Poor of Europe and Central Asia Cope with the Cold World Bank, Washington, D.C.

Latour B 1998 On Actor Network Theory: a few clarifications (http://www.nettime.org/ListsArchives/nettime-l-9801/msg00019.html) Accessed on 4th February, 2008

Lewis R 1979 Science and Industrialization in the USSR Macmillan, New York

Marangos J 2002 A political economy approach to the neoclassical model of transition American Journal of Economics and Sociology 61 259-276

Massey D 1993 Power-geometry and a progressive sense of place in Bird J, Curtis B, Putnam T and Robertson G eds Mapping the Futures: Local Cultures, Global Change Routledge, London and New York 59 - 69

McNeill D 2001 Embodying a Europe of the cities: geographies of mayoral leadership Area 33 353-359

Murray C 2007 How the Russians plan to invade Britain The Daily Mail 27th May 2007

Neumayer E 2008 Distance, power and ideology: diplomatic representation in a world of nation-states Area 40 228-236

O'Lear S 2004 Resources and conflict in the Caspian Sea Geopolitics 9 161-186

Pallot J and Shaw D 1982 Planning in the Soviet Union Croom Helm, London

PEEE (Platts Energy in East Europe) 2007 Jockeying for position and power in 2007 5th January, 2007

Pešić RV and Ürge-Vorsatz D 2001 Restructuring of the Hungarian electricity industry Post-Communist Economies 85-99

Pryke M 1999 City rhythms: neo-liberalism and the developing world in Allen J, Massey D and Pryke M eds Unsettling Cities Routledge, London 229-269

SECQ (Southeastern Europe Commercial Quarterly) 2004 Albania's energy sector - an electrifying future Winter 2004-2005 5-7

Sharp JP, Routledge P, Philo C and Paddison R 2000 Entanglements of power: 
geographies of domination/resistance in Sharp JP, Routledge P, Philo C and Paddison R eds Entanglements of Power: Geographies of Domination/Resistance Routledge, London and New York 1-42

Solomon B, Pasqualetti M and Lushinger D 2004 Energy geography in Gaile GL and Willmott CJ eds Geography in America at the Dawn of the 21 st Century Oxford University Press, Oxford 302-313

Star SL 1999 The Ethnography of infrastructure American Behavioral Scientist 43 377-391

Stern J 2002 Security of European Natural Gas Supplies: The Impact of Import Dependence and Liberalization Royal Institute of International Affairs, London

Stern J and Davis JR 1998 Economic reform of the electricity industries of Central and Eastern Europe Economics of Transition 6 427-460

Sýkora L 2008 Revolutionary change, evolutionary adaptation and new path dependencies: socialism, capitalism and transformations in urban spatial organization in Strubelt W and Gorzelak $\mathbf{G}$ eds City and Region. Papers in Honour of Jiři Musil Budrich UniPress \& Farmington Hills, Leverkusen Opladen 283-295

Ürge-Vorsatz D, Mez L., Miladinova G, Antipas A, Bursik M, Baniak A, Jánossy J, Nezamoutinova D, Beranek J and Drucker G. 2003 The Impact of Structural Changes in the Energy Sector of CEE Countries on the Creation of a Sustainable Energy Path European Parliament, Luxembourg

Ürge-Vorsatz D, Miladinova G and Paizs L 2006 Energy in transition: From the iron curtain to the European Union Energy Policy 34 2279-2297

von Hirschhausen C and Wälde TW 2001 The end of transition: an institutional interpretation of energy sector reform in Eastern Europe and the CIS Moct-Most: Economic Policy in Transitional Economies 11 93-110

von Hirschhausen C and Zachmann G 2005 Perspectives and Challenges of EU Electricity Enlargement - Benchmarking the Reforms of the Electricity Sector in the New Member States WP 5 Report of the SESSA Project (European Forum on Elctricity Regulation), Berlin

Westphal K 2006 Energy policy between multilateral governance and geopolitics: whither Europe? International Politics and Society 2006 44-62

Whatmore S 2002 Hybrid Geographies Sage, London

Xu Y-c 2006 The myth of the single solution: electricity reforms and the World Bank Energy $31802-814$

Yavlinsky G and Braguinsky S 1994 The inefficiency of laissez-faire in Russia: hysteresis effects and the need for policy-led transformation Journal of Comparative Economics 19 88-116 
Table 1: Key environmental indicators about the energy economies of ECE states, 2005

\begin{tabular}{|l|c|c|c|}
\hline & $\begin{array}{l}\text { CO2 emissions per } \\
\text { capita (in tons) }\end{array}$ & $\begin{array}{l}\text { CO2 emissions } \\
\text { per GDP (in } \\
\text { kg/95 \$US) }\end{array}$ & $\begin{array}{l}\text { Energy intensity } \\
\text { (expressed as a } \\
\text { share of the } \\
\text { energy intensity } \\
\text { of Germany) }\end{array}$ \\
\hline Lithuania & 5.53 & 1.34 & $105 \%$ \\
\hline Macedonia & 4.11 & 2.36 & $106 \%$ \\
\hline Albania & 1.16 & 0.82 & $111 \%$ \\
\hline Bosnia & 3.51 & 2.21 & $114 \%$ \\
\hline Hungary & 5.91 & 1.13 & $120 \%$ \\
\hline Slovenia & 8.39 & 0.8 & $122 \%$ \\
\hline Poland & 7.42 & 1.61 & $123 \%$ \\
\hline Croatia & 5.01 & 1.06 & $130 \%$ \\
\hline Slovakia & 7.1 & 1.67 & $135 \%$ \\
\hline Romania & 4.49 & 2.33 & $140 \%$ \\
\hline Latvia & 3.3 & 0.87 & $140 \%$ \\
\hline Estonia & 13.89 & 2.8 & $146 \%$ \\
\hline Czech Republic & 10.94 & 1.86 & $151 \%$ \\
\hline Bulgaria & 6.5 & 3.58 & $154 \%$ \\
\hline Serbia & 4.75 & 1.41 & $371 \%$ \\
\hline
\end{tabular}

Source: Data compiled from the US Energy Information Administration, International Energy Agency, Austrian Energy Agency. 
Figure 1: Share of hydropower and nuclear energy in the total generating capacity of ECE states

Source: Data compiled from the US Energy Information Administration, International Energy Agency, Austrian Energy Agency.

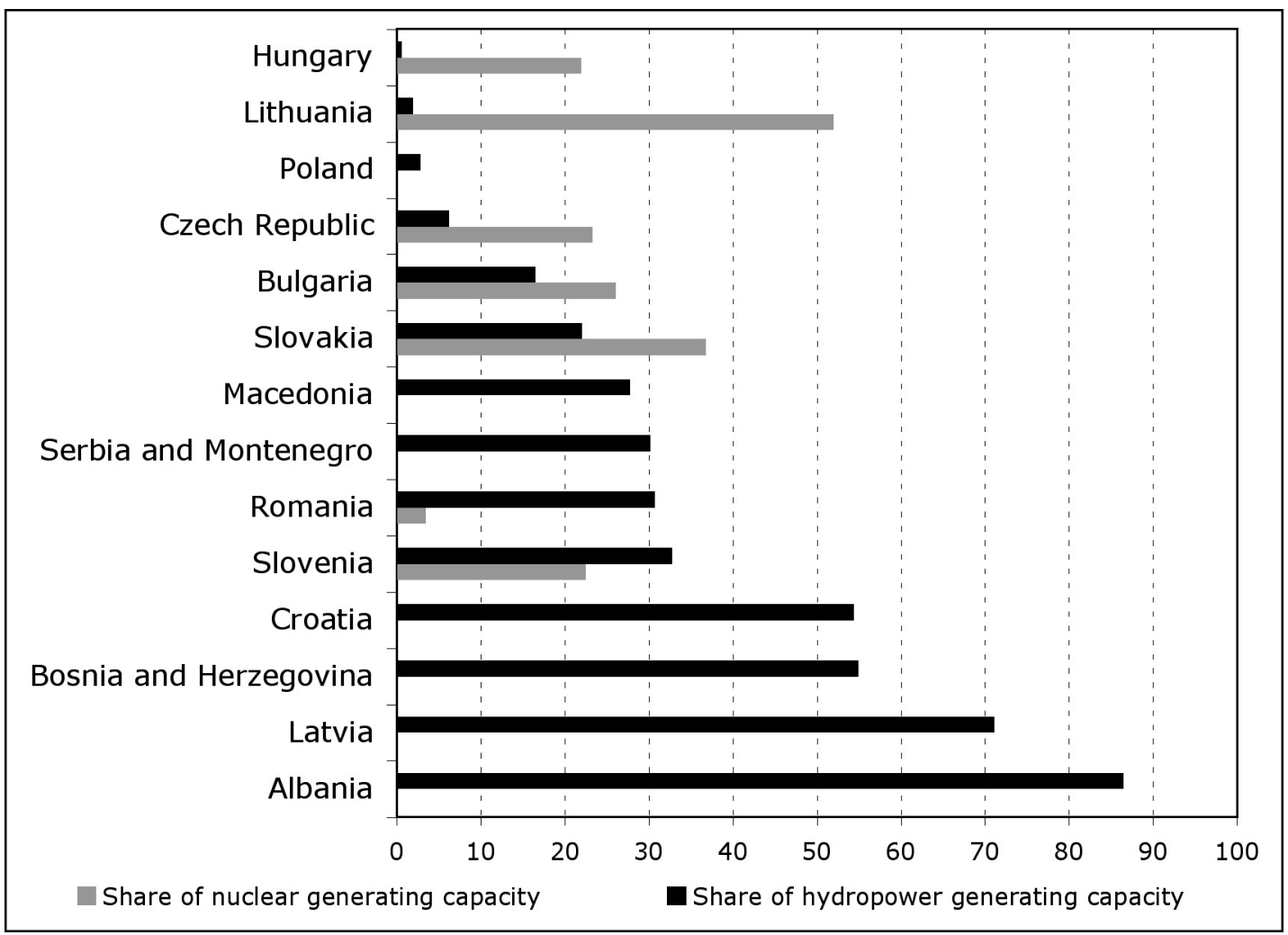




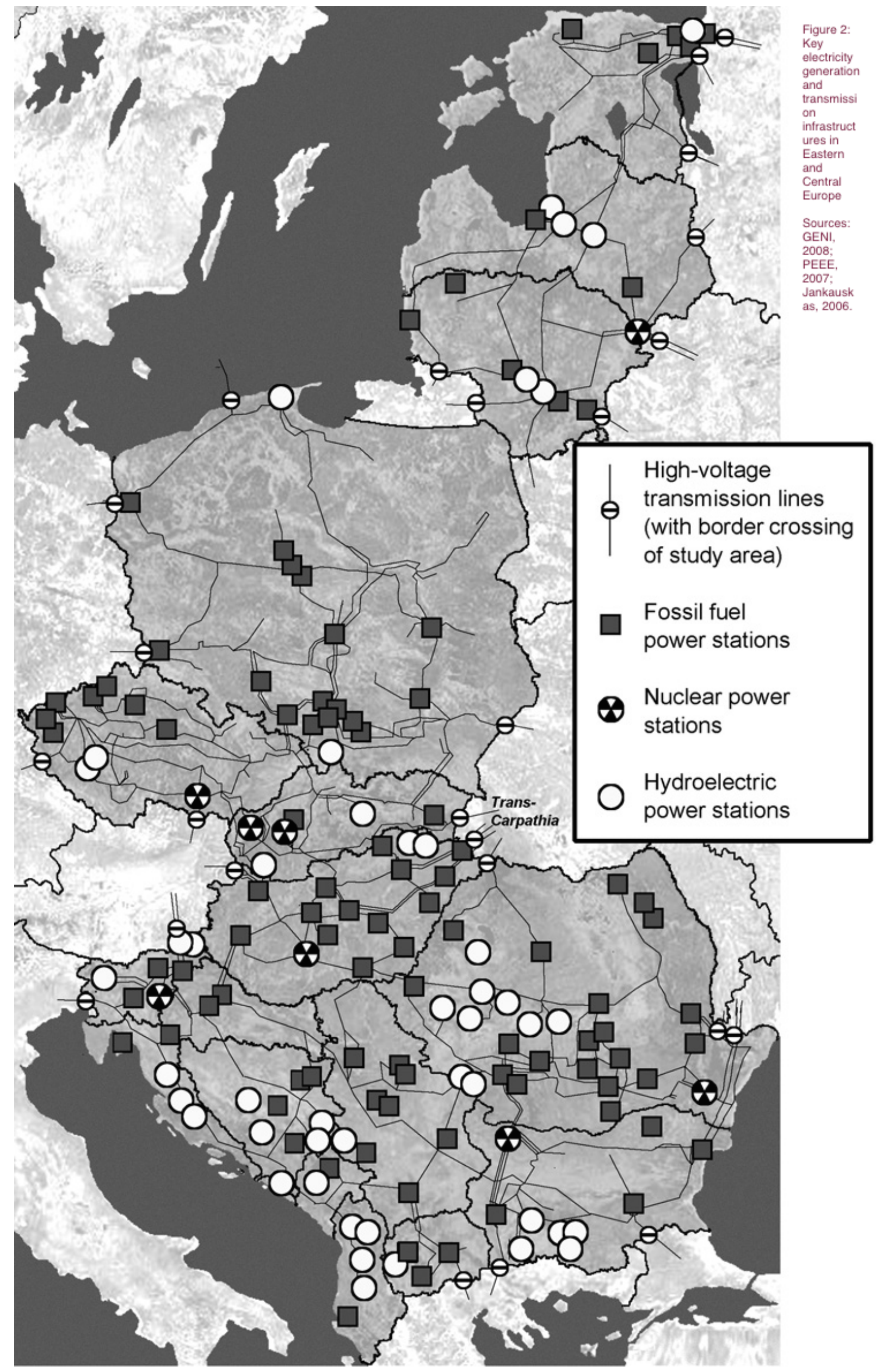

